\title{
Glycogenesis and Glyconeogenesis in Human Platelets
}

\author{
INCORPORATION OF GLUCOSE, PYRUVATE, AND \\ CITRATE INTO PLATELET GLYCOGEN; GLYCOGEN \\ SYNTHETASE AND FRUCTOSE-1,6-DIPHOSPHATASE ACTIVITY
}

\author{
Simon Karpatkin, Arthur Charmatz, and Ruchard M. Langer \\ From the Department of Medicine, New York University Medical Center, \\ New York 10016
}

A B S T R A C T Washed human platelets are capable of depositing 1-4 as well as probable 1-6 glucosyl linkages onto preexistent glycogen primer. They are also capable of degrading (glycogenolysis) newly synthesized $1-4$ as well as probable 1-6 glucosyl linkages. A higher rate of glycogen synthesis was found in platelet suspensions containing lower concentrations of platelets. This was shown to result from decreased glycogen degradation and consequent increased residual glycogen primer in low platelet suspensions. The increased glycogen content of low platelet suspensions was not a result of platelet washing, removal of platelets from plasma, or release of platelet metabolites into the media. The enzyme glycogen synthetase was found to be present at a rate of $5.2 \mu$ moles of uridine diphosphate (UDP) glucose incorporated into glycogen per gram platelets per hour at $37^{\circ} \mathrm{C}$. The $K_{m}$ for UDP glucose was 6.6 mmoles/liter. At optimum concentration of glucose 6-phosphate, the $K_{m}$ was reduced 4.6 fold and $\mathrm{V}_{\max }$ was increased 4.3-fold.

Human platelets contain the glyconeogenic pathway. They incorporate pyruvate- ${ }^{14} \mathrm{C}$ and citrate $-{ }^{14} \mathrm{C}$ into platelet glycogen and contain an apparent fructose-1,6-diphosphatase. The apparent fructose-1,6-diphosphatase was activated by adenosine monophosphate (AMP) and adenosine diphosphate (ADP), inhibited by adenosine triphosphate (ATP), and shown to be rate limiting for glyconeogenesis at physiologic concentration of adenine nucleotide.

\section{INTRODUCTION}

Human platelets have a predominantly aerobic glycolytic metabolism $(1,2)$. They contain considerable glycogen

Dr. Karpatkin is a Career Scientist of the Health Research Council of the City of New York (I-459).

Received for publication 2 July 1969 and in revised form 18 August 1969. stores, equivalent to those of skeletal muscle $(1,3)$. Glycogenolysis in human platelets represents approximately $50 \%$ of glycolytic flux through the EmbdenMeyerhof pathway in the presence of physiologic concentrations of glucose $(1,3)$. Human platelets contain a glycogen degradative enzyme, phosphorylase, which is similar in some respects to that of skeletal muscle (4) but different in other respects (5).

This investigation was designed to determine whether glycogen synthesis takes place in human platelets and whether the "gluconeogenic" pathway was present, i.e., conversion of pyruvate and citrate to glucose or glycogen. Isotopic labeling techniques were employed to measure incorporation of precursor into glycogen. The extent of glycogen labeling was determined by techniques which employed the isolation of previously labeled platelet glycogen during intervals of glycogen synthesis and glycogen degradation. The isolated platelet glycogen was then analyzed for 1-4 glucosyl linkages by specific enzymatic degradation.

\section{METHODS}

Fresh human platelets were obtained, washed, processed, and incubated at $37^{\circ} \mathrm{C}$ as described previously $(1,3,6)$.

All materials were obtained from vendors as described previously $(1,3,6)$. Uniformly labeled glucose- ${ }^{12} \mathrm{C}, 261 \mathrm{mc} /$ mmole, citrate ${ }^{14} \mathrm{C}$ labeled in the $1-5$ position, $1.84 \mathrm{mc} /$ mmole, and uniformly labeled uridine diphosphoglucose- ${ }^{14} \mathrm{C}$ (UDPG), $204 \mathrm{mc} / \mathrm{mmole}$ were obtained from NuclearChicago Corporation, Des Plaines, Ill. Uniformly labeled pyruvate- ${ }^{14} \mathrm{C}, 10.5 \mathrm{mc} / \mathrm{mmole}$ was obtained from International Chemical \& Nuclear Corp., Burbank, Calif. $\beta$-Amylase, phosphorylase, amylo-1,6-glucosidase, yeast phosphohexose isomerase, and fructose-1,6-diphosphate were obtained from Sigma Chemical Co., St. Louis, Mo. Fructose-1,6-diphosphatase $(1.1 \mathrm{U} / \mathrm{mg})$ was obtained from Worthington Biochemical Corp., Freehold, N. J.

Adenosine triphosphate (ATP), glucose, and lactate were assayed enzymatically from neutralized perchloric acid extracts, as described previously $(1,3)$. Fructose-1,6-diphosphate was assayed by coupling the fructose-1,6-diphospha- 
tase reaction to hexose isomerase and glucose 6-phosphate dehydrogenase and measuring the change in absorbance of triphosphopyridine nucleotide (NADP) to its reduced form, $\mathrm{NAPDH}$, at $340 \mathrm{~m} \mu$. The final concentration of reagents employed were $0.46 \mathrm{~mm} \mathrm{NADP}, 12.5 \mathrm{~mm} \mathrm{MgCl}_{2}, 2 \mu \mathrm{g} / \mathrm{ml}$ glucose 6-phosphate dehydrogenase, $8 \mu \mathrm{g} / \mathrm{ml}$ hexose isomerase, $40 \mu \mathrm{g} / \mathrm{ml}$ fructose-1,6-diphosphatase, $20 \mathrm{~mm}$ mercaptoethanol (MSH), in $50 \mathrm{~mm}$ Tris buffer, $\mathrm{pH} 7.5$, and $200 \mu \mathrm{l} / \mathrm{ml}$ of neutralized perchlorate tissue extract. The reaction was started with addition of hexose isomerase.

Isotope experiments. Platelets were incubated in the presence of sufficient ${ }^{14} \mathrm{C}$ isotope to provide $1 \times 10^{6} \mathrm{cpm} / \mathrm{ml}$ incubation fluid. Various combinations of labeled and unlabeled glucose, pyruvate, or citrate were added to the incubation media. After appropriate incubation, glycogen was prepared from platelets by extraction with $33 \% \mathrm{KOH}$ at $100^{\circ} \mathrm{C}$ followed by two alcohol precipitations. Glycogen was assayed with anthrone reagent as described previously $(3,6)$. Glycogen molarity is expressed as glucose units. The labeled glycogen was dissolved in $1 \mathrm{ml}$ of distilled water and an aliquot pipetted into a glass counting vial containing Bray's solution (7). Radioactivity was determined in a Beckman LS100 scintillation spectrometer with isoset adjusted to give $96 \%$ counting efficiency. The radioactivity in the glycogen samples was 60 times background after incubating platelets with glucose $-{ }^{14} \mathrm{C}, 20$ times background with pyruvate $-{ }^{14} \mathrm{C}$, and 6-7 times background in citrate- ${ }^{14} \mathrm{C}$ experiments. The counting error was less than $3 \%$. Control experiments revealed that addition of unlabeled platelet glycogen samples did not reduce the counting efficiency of a standard quantity of radioactivity. The concentration of tissue sample employed for radioactivity measurements was well within the equal linear range of sample concentration addition vs. radioactivity obtained.
$\beta$-Amylase digestion of platelet glycogen. This procedure was a minor modification of the method of Steinetz (8). Briefly, $100 \mu \mathrm{g}$ of $\beta$-amylase was incubated with $1 \mathrm{mg}$ of platelet glycogen in $1 \mathrm{ml}$ of $\mathrm{NaAc}$ buffer, 16 mmoles/liter, $\mathrm{pH} 4.8$ for $14 \mathrm{hr}$ at $25^{\circ} \mathrm{C}$. These incubation conditions were found to be optimum. In control samples, $\beta$-amylase was replaced by a comparable volume of buffer. The glycogen samples were then precipitated and redissolved. The difference in radioactivity and glycogen content between control and enzyme digested samples represented the 1-4 linked tier of branched glycogen beyond the 1-6 glucosyl linkage. The limit dextrin obtained could be hydrolyzed to less than $5 \%$ of original radioactivity, as well as glycogen content, by incubation with phosphorylase and amylo-1,6-glucosidase for $20 \mathrm{hr}$ at $25^{\circ} \mathrm{C}$.

Glycogen synthetase was measured by a radioisotopic procedure which was essentially a modification of the procedure of Villar-Palasi and Larner (9). The platelet pellet was frozen in liquid nitrogen, ground in sand to a fine powder, and extracted in three times its volume of $50 \mathrm{~mm}$ Tris buffer, $\mathrm{pH} 8.2$ containing $5 \mathrm{~mm}$ ethylenediaminetetraacetate(EDTA) and $5 \mathrm{~mm} \mathrm{MSH}$. The optimal concentration of $\mathrm{MSH}$ found to produce maximal enzyme activity was 5 mmoles/liter. The extract was centrifuged at $4000 \mathrm{~g}$ at $4^{\circ} \mathrm{C}$ and the supernatant employed for glycogen synthetase determination. The preparation was stable at $4^{\circ} \mathrm{C}$ for at least 1 wk. A $0.1 \mathrm{ml}$ aliquot was added to $0.4 \mathrm{ml}$ of enzyme incubation solution at $37^{\circ} \mathrm{C}$ for $15 \mathrm{~min}$ containing (final concentration): UDPG- ${ }^{14} \mathrm{C}, 1 \times 10^{\circ} \mathrm{cpm} / \mathrm{ml}$ (varying concentration of unlabeled UDPG), $0.5 \mathrm{~g} / 100 \mathrm{ml}$ glycogen, $5 \mathrm{~mm}$ $\mathrm{MSH}, 5 \mathrm{~mm}$ EDTA, $50 \mathrm{~mm}$ Tris buffer, $\mathrm{pH} 8.2$, and varying concentration of glucose-6-phosphate. The incubation was terminated by the addition of $33 \% \mathrm{KOH}$, the glycogen extracted, and radioactivity assayed as described above.

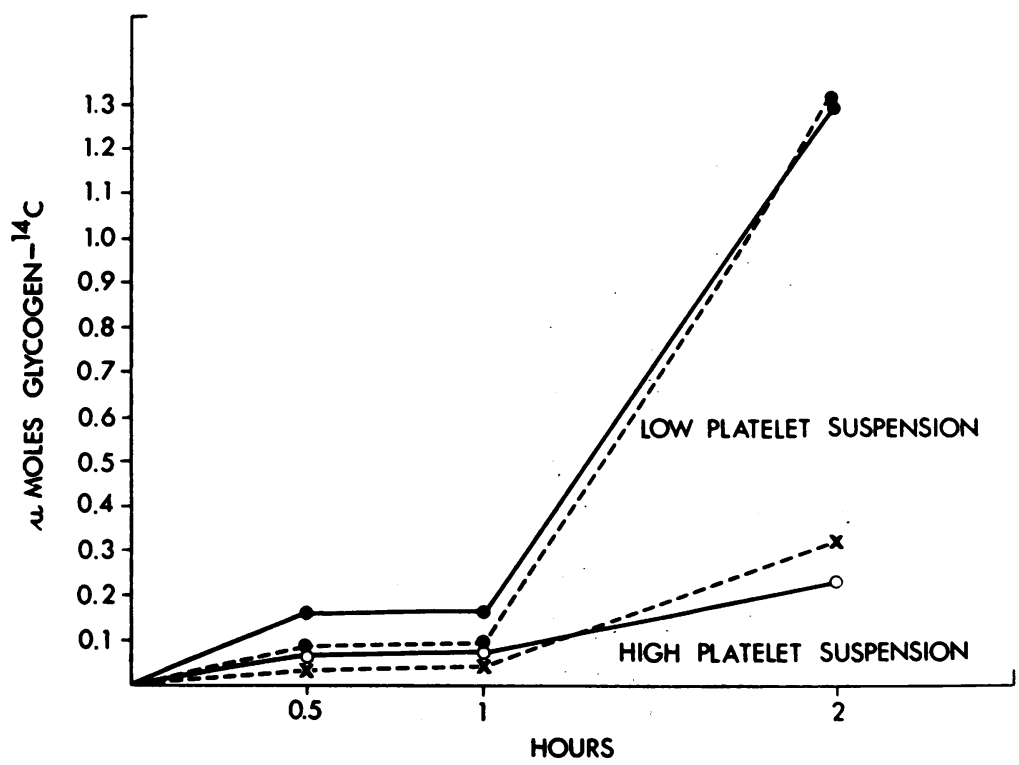

FIGURE 1 Effect of platelet concentration on incorporation of glucose- ${ }^{14} \mathrm{C}$ into platelet glycogen. Washed human platelets were incubated with $5 \mathrm{~mm}$ glucose, $1 \times 10^{\circ} \mathrm{cpm} / \mathrm{ml}$, at $37^{\circ} \mathrm{C}$ at two platelet suspension concentrations : $0.5 \%, \bullet$; and $5 \%, \bigcirc, \times$. Data are expressed as $\mu$ moles $/ g$ wet weight, _ and $\mu$ moles $/ 10 \mu$ moles glycogen, - - - - Each time point represents 4-6 experiments. SEM was $10 \%$ or less. 


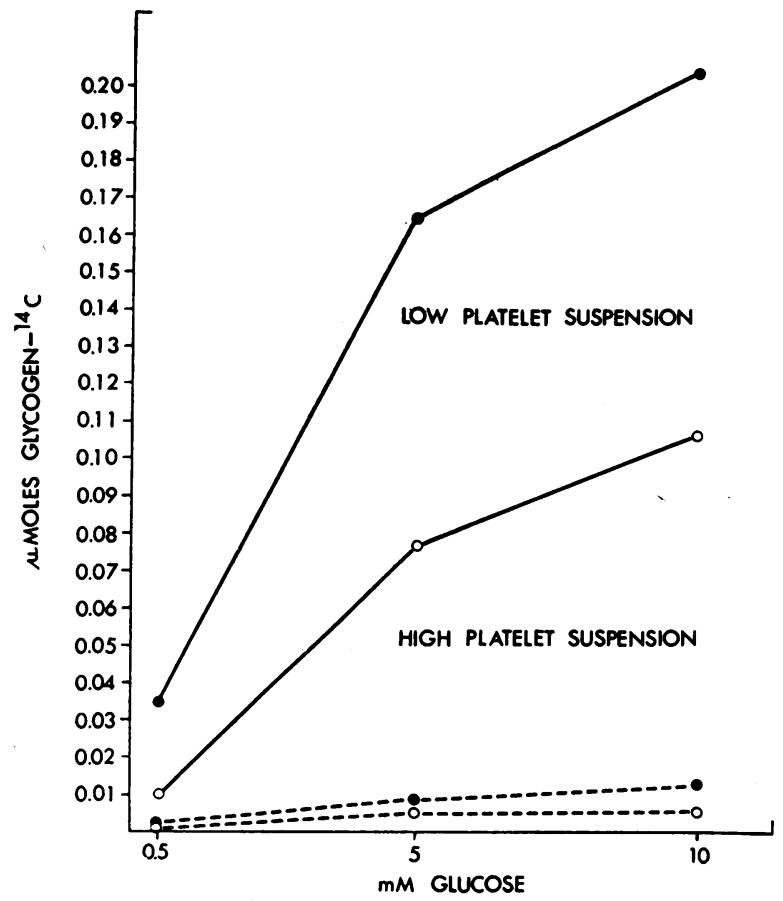

FIGURE 2 Effect of glucose concentration on incorporation of glucose $-{ }^{14} \mathrm{C}$ into platelet glycogen. Washed human platelets were incubated with $0.5,5$, and $10 \mathrm{~mm}$ glucose, $1 \times 10^{\circ}$ $\mathrm{cpm} / \mathrm{ml}$ at $37^{\circ} \mathrm{C}$ for $1 \mathrm{hr}$ at two platelet suspension concentrations: $0.5 \%$, $\bullet$; and $5 \%$, $\bigcirc$. Data are expressed as $\mu$ moles/g wet weight, - $\ldots$, and $\mu$ moles $/ 10 \mu$ moles glycogen, - - - . Each time point represents four experiments. SEM was $10 \%$ or less.

The reaction was linear with time and enzyme extract concentration. Control experiments revealed negligible adsorption of UDPG- ${ }^{14} \mathrm{C}$ to glycogen in the glycogen isolation procedure. All counts were at least 100 times background and counting error was less than $0.5 \%$.

An enzyme with fructose-1,6-diphosphatase activity was prepared from a frozen platelet pellet treated as above for glycogen synthetase but extracted in three times its volume of $50 \mathrm{~mm}$ Tris buffer, $\mathrm{pH} 7.5$, and $20 \mathrm{~mm}$ MSH. The extract was similarly centrifuged and enzyme activity of the supernatant measured. Further purification of this enzyme was obtained by extraction in $40 \mathrm{mg} / \mathrm{ml}$ charcoal (Norite A), followed by centrifugation at $105,000 \mathrm{~g}$ for $60 \mathrm{~min}$ at $4^{\circ} \mathrm{C}$. The supernatant was treated with crystalline $\left(\mathrm{NH}_{4}\right)_{2} \mathrm{SO}_{4}$ at $4^{\circ} \mathrm{C}$, which served to precipitate the enzyme at the $24-32$ $\mathrm{g} / 100 \mathrm{ml}$ fraction. This resulted in a 20 -fold purification and $10 \%$ yield from the $4000 \mathrm{~g}$ platelet extract supernatant. The specific activity of this preparation at $\mathrm{pH} 7.5,30^{\circ} \mathrm{C}$ was 1 umole fructose 6 -phosphate/min per $\mathrm{mg}$ protein. This preparation was stable for several hours at $0^{\circ} \mathrm{C}$, losing variable degrees of activity after storage overnight at $4^{\circ} \mathrm{C}$. The final assay cuvette concentration contained 50-100 $\mu \mathrm{l} /$ ml platelet extract, $0.46 \mathrm{~mm}$ NADP, 0.1-2 mM fructose-1,6diphosphate, $4 \mu \mathrm{g} / \mathrm{ml}$ glucose 6-phosphate dehydrogenase, $16 \mu \mathrm{g} / \mathrm{ml}$ hexose isomerase, and $20 \mathrm{~mm} \mathrm{MSH}$, in $50 \mathrm{~mm}$ Tris buffer, pH 7.5 (10). For orthophosphate release experiments, an assay was employed which was described previously (3).
TABLE I

Effect of Platelet Concentration on Glycogen Depletion, Lactate Production, and ATP Depletion*

\begin{tabular}{cccc}
\hline $\begin{array}{c}\text { Platelet } \\
\text { suspension }\end{array}$ & $\begin{array}{c}\text { Glycogen } \\
\text { depletion } \\
\text { at } 1 \mathrm{hr}\end{array}$ & $\begin{array}{c}\text { Lactate } \\
\text { production }\end{array}$ & $\begin{array}{c}\text { ATP level } \\
\text { at } 1 \mathrm{hr}\end{array}$ \\
\hline & $\mu$ moles $/ \mathrm{g}$ & $\mu$ moles $/ \mathrm{g} \mathrm{per} \mathrm{hr}$ & $\mu$ moles $/ \mathrm{g}$ \\
$0.5 \%$ & $12.5 \pm 0.80(5) \ddagger$ & $24.4 \pm 4.2 \S(5)$ & $2.01(3)$ \\
$5.0 \%$ & $18.6 \pm 0.91(7)$ & $35.0 \pm 5.8(5)$ & $1.51(3)$ \\
\hline
\end{tabular}

* Data given for washed human platelets incubated at $37^{\circ} \mathrm{C}$ for $1 \mathrm{hr}$ in the presence of $5 \mathrm{~mm}$ glucose.

$\ddagger$ Number of experiments.

$\S$ SEM differences are significant at $P<0.01$ level.

\section{RESULTS}

Glycogen synthesis with glucose as precursor

Effect of platelet concentration. The rate of incorporation of $\mathrm{D}$-glucose $-{ }^{14} \mathrm{C}$ into platelet glycogen was measured at a physiologic platelet concentration of $0.5 \%$ (or $380,000 / \mathrm{mm}^{3}$ ) and at a more concentrated platelet concentration of $5 \%$. To our surprise, the less concentrated platelet suspension incorporated considerably more glucose into glycogen at $1 / 2,1$, and particularly $2 \mathrm{hr}$, Fig. 1. Similar results were obtained when data were expressed per milliliter platelets, or when different concentrations of extracellular glucose were employed, Fig. 2. Platelets incubated at physiologic concentration also exhibited slower rates of glycogen depletion and lactate production than the more concentrated suspensions used previously $(1,3,6)$, Table I. Platelets incubated at high concentration did not aggregate macroscopically or microscopically and behaved identically when incubated in plasma ( $20 \mathrm{~mm}$ glucose), Table II.

TABLE II

Effect of Platelet Concentration in Plasma and Human Ringer Solution on Glycogen Depletion and Lactate Production in the Presence of $20 \mathrm{~mm}$ Glucose

\begin{tabular}{ccccc}
\hline & \multicolumn{2}{c}{ Plasma } & & \multicolumn{2}{c}{ Human Ringer } \\
\cline { 2 - 4 } \cline { 4 - 5 } & $0.58 \% \ddagger \quad 4.37 \%$ & & $0.58 \%$ & $4.37 \%$ \\
\hline
\end{tabular}

Lactate

production, $\mu$ mole $/ \mathrm{g} / \mathrm{hr}$

$21.5 \quad 31.3$

18.8

35.4

Glycogen

depletion

at $1 \mathrm{hr}$,

$\mu$ mole $/ g$

$6.7 \quad 11.6$

8.2

13.1

* Platelets were incubated at $37^{\circ} \mathrm{C}$ for $1 \mathrm{hr}$ in their original plasma and in a human Ringer solution adjusted to the glucose concentration of the plasma.

$\S$ Platelet suspension. 


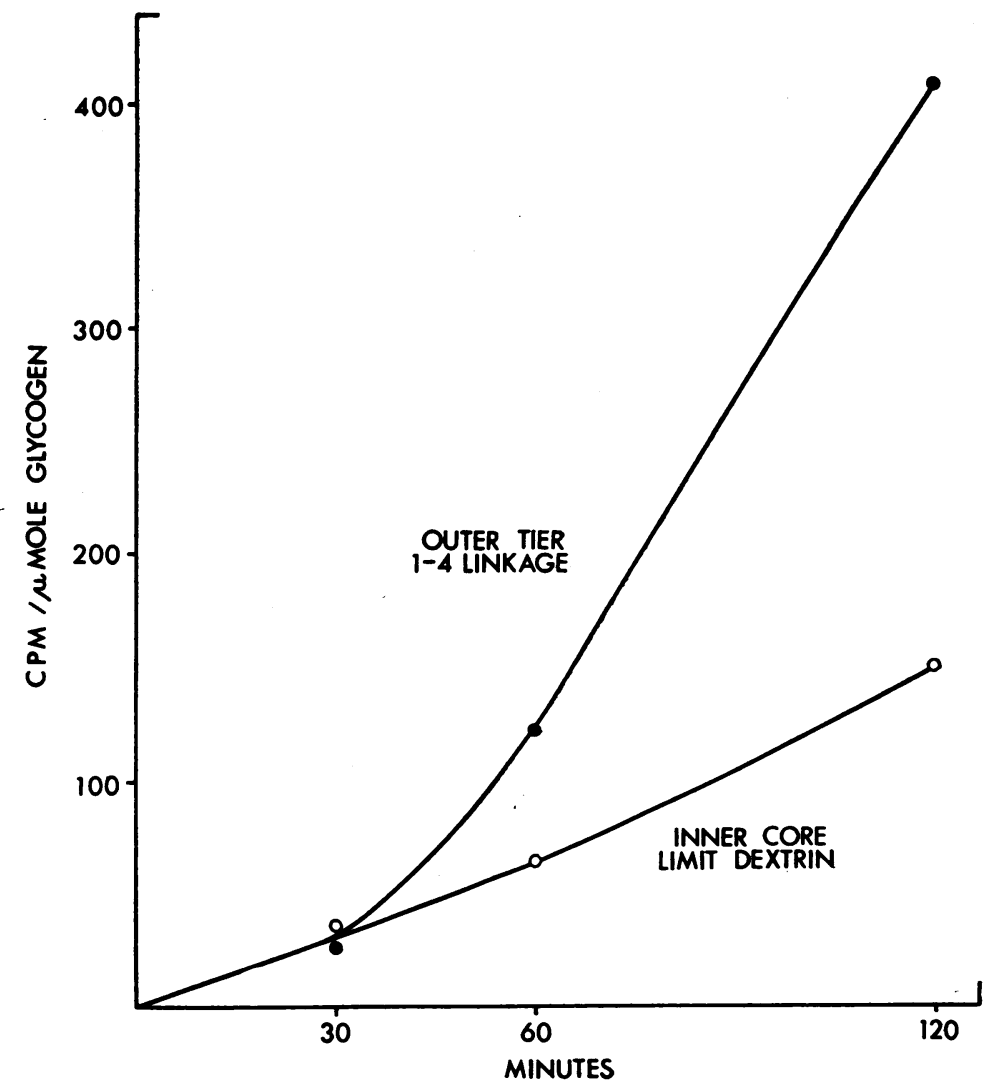

FIgURE 3 Examination of labeled platelet glycogen limit dextrin and outer tier (1-4 linkages) during glycogen synthesis. Washed platelets were labeled with glucose- ${ }^{14} \mathrm{C}$ to form labeled glycogen by incubating a $5 \%$ suspension in $5 \mathrm{~mm}$ glucose, $1 \times 10^{\circ} \mathrm{cpm} / \mathrm{ml}$ at $37^{\circ}$ for varying time intervals. The platelet glycogen was then isolated and treated with $\beta$-amylase to remove available 1-4 linkages, $-\longrightarrow$, (see Methods). The remaining core, represented limit dextrin, $\mathrm{O}-\mathrm{O}$, was assayed for glycogen content as well as radioactivity. Total platelet glycogen and radioactivity were obtained from control samples similarly handled but not treated with $\beta$-amylase. Data are expressed as $\mathrm{cpm} / \mu$ mole glycogen. Each time point represents 4-7 experiments, except the last time point which represents the average of two experiments. SEM was $10 \%$ or less.

In view of the glycogen synthesis data of Figs. 1 and 2 , it seemed likely that higher glycogen synthesis took place in association with higher platelet glycogen levels. This in turn strongly suggested that platelet glycogen was acting as a primer for further glucosyl unit deposition on outer tiers of preexistent glycogen branches.

Examination of platelet glycogen prelabeled with glucose ${ }^{2}{ }^{14} C^{2}$ during glycogen synthesis. Platelets were incubated in human Ringer's solution with glucose- ${ }^{14} \mathrm{C}$

\footnotetext{
${ }^{1}$ Because of the requirement of prohibitive quantities of radioisotopes for the incubation of significant numbers of platelets at physiologic platelet concentrations, all further experiments were performed with platelet suspensions of $5 \%$. As will be noted, the information desired did not require the use of physiologic platelet concentrations.
}

for varying periods of time, the labeled glycogen isolated, and the degree of labeling of outer glycogen branch tier (1-4 linkages) compared with that of the inner core (limit dextrin) obtained after $\beta$-amylase digestion. (This enzyme digests the outer tier, 1-4 linkages.) The specific activity of the outer 1-4 linkage tier increased up to $2 \mathrm{hr}$, (Fig. 3). The specific activity of the inner core increased exponentially as would be expected if new glucosyl units were deposited on already existent glycogen branches, some of which were then converted to 1-6 linkages (followed by 1-4 linkages).

During glycogen degradation. Platelets were incubated for $1 \mathrm{hr}$ at $37^{\circ} \mathrm{C}$ in the presence of glucose $-{ }^{14} \mathrm{C}$ in order to label platelet glycogen with isotope. The platelets were then collected, washed in human Ringer, and 
then reincubated in human Ringer's solution in the absence of glucose $-{ }^{14} \mathrm{C}$ for varying time intervals. The labeled glycogen was isolated and treated with and without $\beta$-amylase as above. As can be noted from Fig. 4, the per cent of recently synthesized outer chain (1-4 linkages) tiers, with respect to total synthesized glycogen, decreased with increasing interval of incubation of prelabeled platelets. Of interest was the increase in specific activity of prelabeled platelets (counts per minute per micromole glycogen), with increasing incubation time. The specific activity of total labeled glycogen as well as limit dextrin-labeled glycogen increased with time, the latter increasing considerably at $2 \mathrm{hr}$. These data indicated that more unlabeled glycogen was being degraded than labeled glycogen (newly synthesized glycogen), suggesting a nonsequential or heterogeneous mode of glycogen depletion.

\section{Glycogen synthetase}

Fig. 5 depicts kinetic data for platelet glycogen synthetase. The $K_{m}$ in the absence of glucose $\cdot 6$-phosphate was $6.6 \mathrm{mmoles} /$ liter. Theoretical $\mathrm{V}_{\max }$ was 0.033
( $\mu$ moles/0.025 $\mathrm{g}$ wet weight platelets per $15 \mathrm{~min}$ ). Glucose 6-phosphate at nearly optimum concentration increased $V_{\max }$ 4.3-fold to 0.143 and lowered the apparent average $K_{m}$ to $1.43 \mathrm{mmoles} / \mathrm{liter}$ or 4.6 -fold. This indicated that both forms of glycogen synthetase (i.e. independent glucose 6-phosphate form, I, and dependent glucose 6-phosphate form, D) are present in human platelets. At physiologic levels of glucose 6-phosphate in platelets, (1) $0.05 \mathrm{mmole} / \mathrm{liter}$, glycogen synthetase activity is capable of operating at $30 \%$ of theoretical $V_{\text {max. }}$ This represents $7.0 \mu$ moles glycogen synthesized/g per hr.

Glycogenesis with pyruvate and citrate as precursor

Both pyruvate and citrate were incorporated into platelet glycogen, Table III. Free glucose could not be detected in the total incubation platelet suspension with a method capable of detecting $1.5 \times 10^{-6}$ mole/liter. After $1 \mathrm{hr}$ incubation with pyruvate or citrate at $37^{\circ} \mathrm{C}$, optimum pyruvate incorporation into glycogen was at 20 mmoles/liter and optimum citrate incorporation into

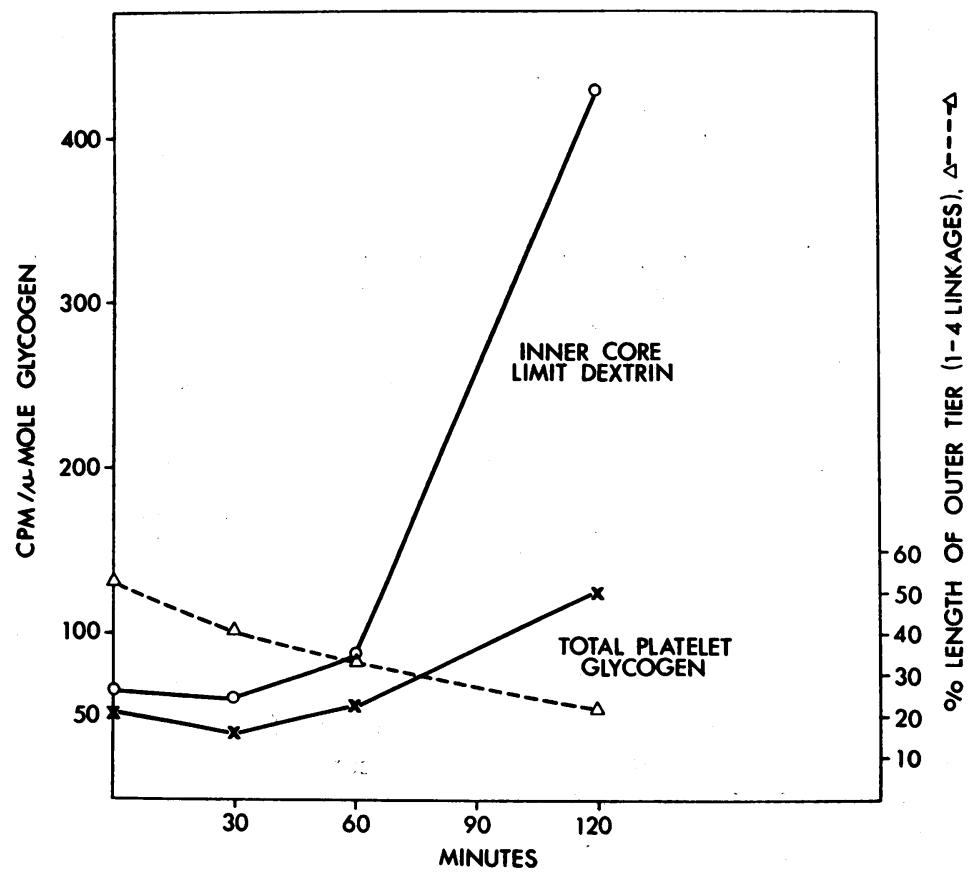

FIgURE 4 Examination of labeled glycogen limit dextrin and outer tier (1-4 linkages) during glycogen degradation. Washed platelets were prelabeled for $1 \mathrm{hr}$ by incubation of a $5 \%$ suspension in $5 \mathrm{~mm}$ glucose, $1 \times 10^{\circ} \mathrm{cpm} / \mathrm{ml}$ at $37^{\circ} \mathrm{C}$. These platelets were then washed, resuspended, and reincubated for varying time intervals. The labeled glycogen was isolated at varying time intervals and analyzed for limit dextrin and outer tier (1-4 linkages). Data are expressed as cpm/ $/ \mu$ mole glycogen for total glycogen, $X-X$, and limit dextrin; $\bigcirc-O$. Per cent length of outer tier (1-4 linkages) is also given, $\triangle----\Delta$. Each time point represents four experiments. SEM was $10 \%$ or less. 


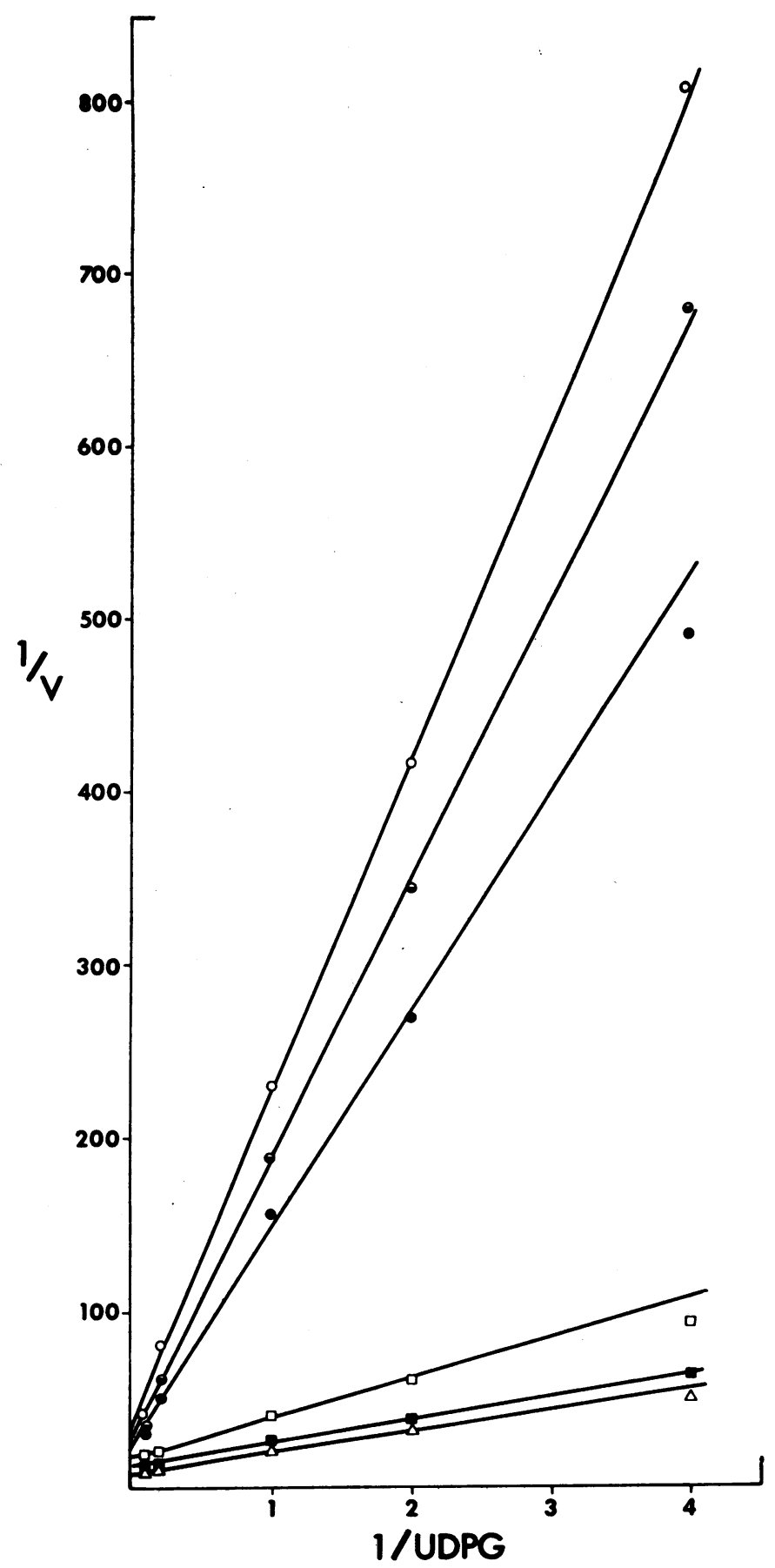

Figure 5 Lineweaver-Burke plot for platelet extract glycogen synthetase activity. See methods for details of UDPG- ${ }^{14} \mathrm{C}$ incorporation into glycogen. Data are given at varying glucose 6-phosphate concentration $\mu$ moles $/ \mathrm{ml}: 0,0 ; 0.05, \Theta ; 0.1, \bullet ; 1, \square ; 2$, - $5, \triangle$. The $K m$ for glycogen synthetase activity at the above mentioned glucose 6 -phosphate concentration was $6.6,7.3,1.44,1.43$, and 1.43 , respectively. $V_{\max }$ was $0.033,0.044,0.046,0.063,0.10$, and 0.143 , respectively. 
TABLE III

Incorporation of Glucose, Pyruvate, and Citrate into Platelet Glycogen*

\begin{tabular}{|c|c|c|c|c|c|c|c|c|}
\hline $\begin{array}{c}\text { Incubation } \\
\text { concen- } \\
\text { tration } \\
\text { mM }\end{array}$ & 5 & 10 & 20 & 40 & 5 & 10 & 20 & 40 \\
\hline & \multicolumn{4}{|c|}{ mumoles $/ \mathrm{g}$ platelets } & \multicolumn{4}{|c|}{ 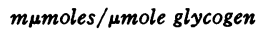 } \\
\hline Glucose & $\begin{array}{c}77.0 \\
(6) \ddagger\end{array}$ & $\begin{array}{c}106.8 \\
(3)\end{array}$ & & & 5.38 & 8.01 & & \\
\hline Pyruvate & 31.2 & 83.3 & $\begin{array}{l}91.4 \\
(14)\end{array}$ & & 2.18 & 5.52 & 6.04 & \\
\hline Citrate & 5.51 & 8.7 & $\begin{array}{r}11.6 \\
(4)\end{array}$ & $\begin{array}{c}31.9 \\
(9)\end{array}$ & 0.34 & 0.63 & 0.92 & 3.18 \\
\hline
\end{tabular}

* Washed human platelets were incubated as a $5 \%$ suspension in human Ringer solution containing varying concentrations of either glucose- ${ }^{14} \mathrm{C}$, pyruvate $-{ }^{14} \mathrm{C}$, or citrate $-{ }^{14} \mathrm{C}$ for $1 \mathrm{hr}$ at $37^{\circ} \mathrm{C}$.

$\ddagger$ Number of experiments is given in brackets. SEM was less than $10 \%$ for all data with four or more experiments.

glycogen was at 40 mmoles/liter ${ }^{2}$ Table III. At concentrations of $5 \mathrm{mmoles} /$ liter, pyruvate was less effective than glucose, and citrate was less effective than pyruvate in incorporation into glycogen. At physiologic glucose concentration, 5 mmoles/liter, net glycogen synthesis from glucose represented $0.08 \mu$ moles $/ g$ per $\mathrm{hr}$ at $37^{\circ} \mathrm{C}$.

\section{Fructose-1,6-diphosphatase activity}

A fructose-1,6-diphosphatase was present in a $4000 \mathrm{~g}$ homogenate of platelets giving a rate of $10.8 \mu$ moles of fructose 6-phosphate/g platelets per $\mathrm{hr}$ at $30^{\circ} \mathrm{C}$ (four experiments with optimal fructose-1,6-diphosphate concentration of 2 mmoles/liter). The rate was linear with increasing homogenate concentration over the range studied and was zero in the absence of fructose-1,6-diphosphate. At the concentration of fructose-1,6-diphosphate present in human platelets $(0.087 \pm 0.006 \mu \mathrm{mole} / \mathrm{g}$, eight experiments), the rate was $5.2 \mu$ mole/g per $\mathrm{hr}$, Table IV.

The enzyme was purified 20 -fold, had a $\mathrm{pH}$ optimum of approximately 7 , and had no $\mathrm{Mg}^{++}$ion requirement. The enzyme was fairly specific for fructose-1,6-diphosphate. The substrates fructose 6-phosphate, glucose 6 -phosphate, glucose 1-phosphate, and $\beta$-glycerol phosphate, at concentrations of 2 mmoles/liter, gave zero

\footnotetext{
${ }^{2}$ Of interest was the observation that citrate incorporation into glycogen was sigmoidal, plateauing at $10 \mathrm{~mm}$ extracellular citrate, but then increasing at $20 \mathrm{mmoles} / \mathrm{liter}$ and plateauing at $40 \mathrm{mmoles} / \mathrm{liter}$ (all data not given). All incubations were maintained at isotonicity by lowering the $\mathrm{NaCl}$ concentration. This observation was not further pursued.
}

TABLE IV

Effect of $A M P, A D P$, and ATP on Fructose-1, 6-Diphosphatase Activity*

\begin{tabular}{|c|c|c|c|c|c|c|c|}
\hline \multicolumn{2}{|c|}{$\begin{array}{c}\text { Concentration mM } \\
\text { Fructose-1, } \\
\text { 6-diphosphate }\end{array}$} & \multicolumn{2}{|c|}{ AMP } & \multicolumn{2}{|c|}{ ADP } & \multirow{2}{*}{$\begin{array}{l}\text { ATP } \\
2.52\end{array}$} & \multirow{2}{*}{$\begin{array}{l}\text { Rate of } \\
\text { fructose } \\
\text { 6-phosphate } \\
\text { at } 30^{\circ} \mathrm{C}\end{array}$} \\
\hline 0.10 & 2.0 & 0.36 & 2.0 & 1.39 & 2.0 & & \\
\hline & & & & & & & 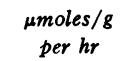 \\
\hline+ & 0 & 0 & 0 & 0 & 0 & 0 & 5.2 \\
\hline+ & 0 & + & 0 & 0 & 0 & 0 & 11.6 \\
\hline+ & 0 & 0 & 0 & + & 0 & 0 & 8.6 \\
\hline+ & 0 & 0 & 0 & 0 & 0 & + & 0 \\
\hline+ & 0 & + & 0 & + & 0 & + & 0.69 \\
\hline 0 & + & 0 & 0 & 0 & 0 & 0 & 10.8 \\
\hline 0 & + & 0 & + & 0 & 0 & 0 & 17.2 \\
\hline 0 & + & 0 & 0 & 0 & + & 0 & 16.8 \\
\hline 0 & + & 0 & + & 0 & + & 0 & 18.0 \\
\hline
\end{tabular}

* A platelet extract obtained from a $4000 \mathrm{~g}$ homogenate, wherein final tissue dilution in the assay cuvette was 40-fold. Data represent the average of two different platelet extracts. $(+)$ refers to presence or absence $(0)$ of substrate or effector concentration.

rates of orthophosphate release after incubation at $30^{\circ} \mathrm{C}$ for $30 \mathrm{~min}$ at $\mathrm{pH} 7.5$ in $50 \mathrm{~mm}$ Veronal buffer or $50 \mathrm{~mm}$ Tris buffer. The $K_{m}$ for fructose-1,6-diphosphate varied between 0.06 and 0.2 mmoles/liter. AMP caused activation of the enzyme, rather than inhibition which has been reported in other tissues $(10,11-13)$, Fig. $6 \mathrm{~A}$, raising $\mathrm{V}_{\max }$ 6-fold. ADP also activated this enzyme, Fig. $6 \mathrm{~B}$, raising $V_{\max }$ 9-fold. ATP was a potent inhibitor of this enzyme, giving zero rates at physiologic concentrations of ATP, 1-3 mmoles/liter (3), employing similar fructose-1,6-diphosphate concentrations as those shown in Fig. 6.

In the presence of physiologic concentrations of fructose-1,6-diphosphate, AMP, ADP, and ATP (3), the rate was $0.69 \mu$ moles/g per $\mathrm{hr}$, Table IV.

\section{DISCUSSION}

Incorporation of glucose $-{ }^{14} \mathrm{C}$ into isolated human platelet glycogen has been reported by Scott (14) and by this laboratory (6). Our present results both confirm and further document these observations. Human platelets are capable of synthesizing new 1-4 and probable 1-6 glucosyl linkages onto preexistent tiers of branched glycogen polymers via glycogen synthetase which has been measured (and presumably amylo 1-4 $\rightarrow$ 1-6 transglucosylase which could be inferred, Fig. 3). The newly synthesized glycogen is also available to the degradative glycogenolytic enzymes, phosphorylase (which has been described in human platelets, 4, 5, 14), and probable amylo-1,6 glucosidase (which could be predicted) since 1-4 as well as probable 1-6 linkages were synthesized and degraded (Figs. 3 and 4). Of considerable interest was 
the observation of a nonsequential or heterogeneous mode of glycogen depletion compared with glycogen synthesis. This might suggest a heterogeneous distribution or compartmentation of glycogenolytic enzymes as compared with the glycogen synthesis enzymes. An al- ternative hypothesis would predict random splitting and rejoining of glycogen branches. Of further interest was the marked increase in glycogen synthesis of low platelet suspensions after $1 \mathrm{hr}$ of incubation. This observation remains unexplained.
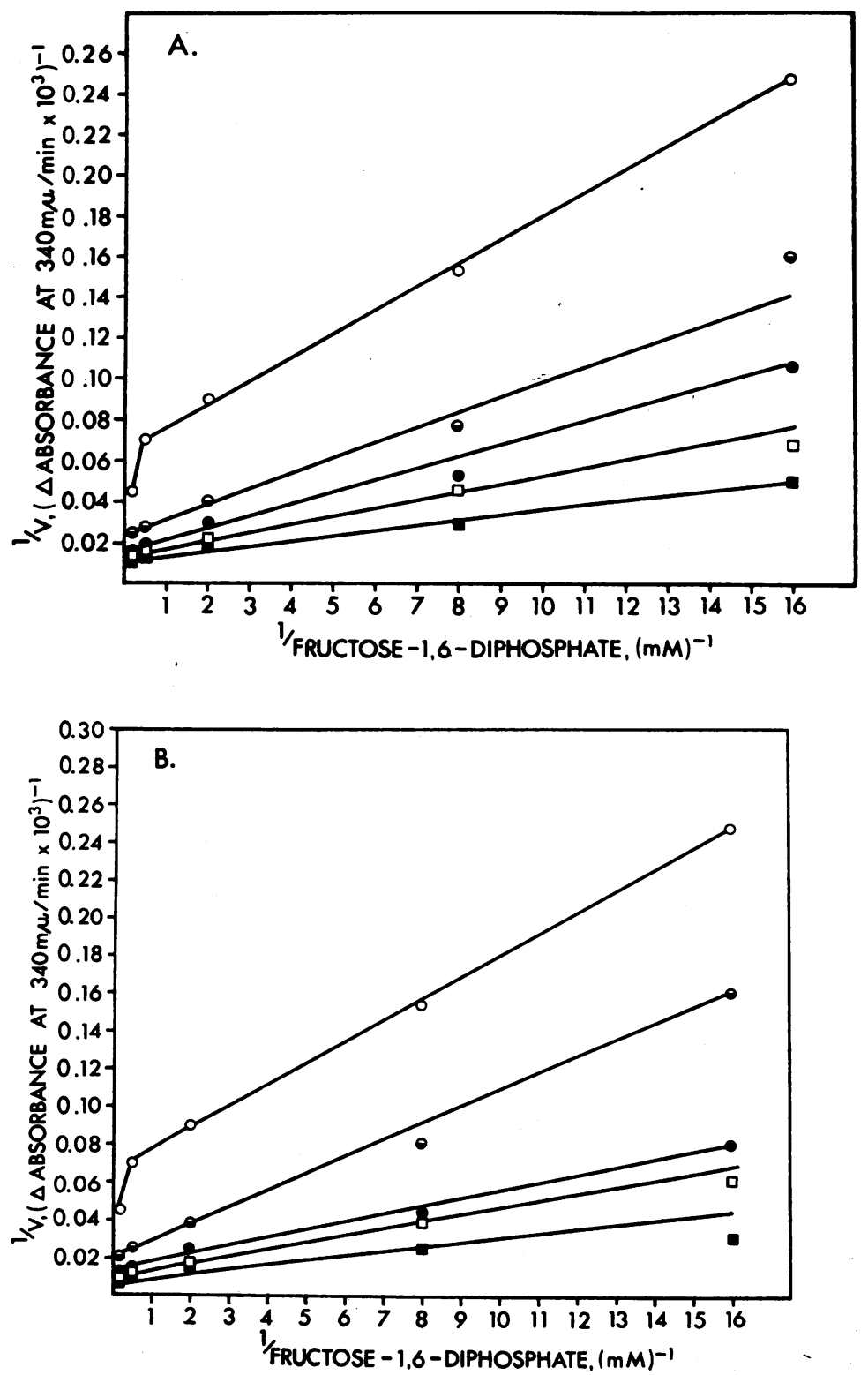

FIgURE 6 (A) Lineweaver-Burke plot for 20-fold purified platelet enzyme with fructose-1,6-diphosphatase activity. See Methods section for details. Data are given at varying AMP concentrations, $\mu \mathrm{moles} / \mathrm{ml}: 0,0$; $0.1, \ominus ; 0.5, \bullet ; 1, \square ; 3, \cdot$. The $K_{m}$ for fructose-1,6-diphosphatase activity was $0.178 \mathrm{mmoles} /$ liter. $\mathrm{V}_{\max }$ at the above mentioned AMP concentrations was $15.6,41.7,62.5,66.7$, and 100 , respectively. (B) Data are given at varying ADP concentrations (same symbols and concentrations as for $A M P$, part $A$ ) for the same enzyme preparation. $V_{\max }$ at these ADP concentrations was $15.6,47.6,71.4,100$, and 143 , respectively. 
Leloir and Cardini have demonstrated glycogen synthesis in liver and muscle from UDPG and glycogen synthetase (15). Glycogen synthetase activity has been reported in pig platelet extracts with the associated glucose 6-phosphate-dependent enzyme by Vainer and Wattiaux (16). The same applies for human platelets.

The two major sites for glyconeogenesis in mammals are the liver and kidney (17). To our knowledge, this is the first report of the full glyconeogenic pathway in platelets as well as fructose-1,6-diphosphatase activity. This might have been predicted from a previous report from this laboratory (1) wherein the Krebs cycle activity in human platelets was emphasized and the first stage of the gluconeogenic pathway was suggested, i.e., human platelets were capable of converting citrate to lactate.

The fructose-1,6-diphosphatase activity of human platelets appears unique in its modulation by AMP, $\mathrm{ADP}$, and ATP and lack of requirement for $\mathrm{Mg}^{++}$ion. AMP, in contrast to its inhibitory effect on other fructose-1,6-diphosphatases $(10,11-13)$, activates the platelet enzyme. Other specific fructose-1,6-diphosphatases from Escherichia coli and Euglena gracilis (10) have been described which are neither activated nor inhibited by AMP. ADP is also a potent activator, whereas ATP inhibits the enzyme. Inhibition of fructose-1,6-diphosphatase by ATP has also been reported in rat and rabbit liver (18). Lack of inhibition by AMP and absence of a $\mathrm{Mg}^{++}$ion requirement makes one cautious in defining this enzyme as a fructose-1,6-diphosphatase rather than a nonspecific phosphatase. However, substrate specificity was exhibited, and the enzyme does have a $K_{m}$ in the range of platelet fructose-1,6-diphosphate concentration. Thus, an enzyme is present in human platelets wh ${ }^{\text {ch }}$ is capable of converting fructose-1,6-diphosphate to fructose 6-phosphate and which can readily explain the conversion of pyruvate or citrate to glycogen.

At physiologic concentration of adenine nucleotide and glucose-6-phosphate, the platelet extract rates of glycogen synthetase (at $37^{\circ} \mathrm{C}$ ) and apparent fructose-1,6diphosphatase $\left(\right.$ at $30^{\circ} \mathrm{C}$ ) are 7 and $0.69 \mu$ moles $\mathrm{g}$ wet weight per hr. These data suggest that fructose-1,6-diphosphatase activity is rate limiting for glycogen synthes $\mathrm{s}$, as it is in other tissues $(19,20)$. Human platelet phosphorylase has a rate at $30^{\circ} \mathrm{C}$ of $11 \mu$ moles glucose 1-phosphate/g per $\mathrm{hr}^{3}$ at physiologic concentration (3) of substrates: glycogen and orthophosphate and known effectors: AMP, ATP, and ADP. This would predict a greater potential for glycogen degradation as compared with glycogen synthesis.

Platelets incubated at high concentration (5\%) exhibit increased glycogen degradation. As a result, there is less glycogen primer and consequently, a lower rate

\footnotetext{
${ }^{3}$ Karpatkin, S., and R. M. Langer. Unpublished data.
}

of glycogen synthesis than in platelets incubated at physiologic concentration $(0.5 \%)$. Of interest is a recent observation by Murphy ${ }^{4}$ wherein 24-hr-stored platelet concentrates at $22^{\circ} \mathrm{C}$ were noted to have 2.3 -fold lower glycogen content than similarly stored platelet-rich plasma. Whether the decreased platelet glycogen of platelet concentrates is responsible for the decreased platelet recovery after platelet concentrate transfusions remains to be established.

The reason for increased glycogen degradation with increased platelet concentration remains unexplained. It is not due to platelet aggregation or removal of platelets from plasma. It is probably not a result of release of a platelet metabolite since rates of lactate production are linear at high platelet suspensions (1). It is conceivable that the increased rate of platelet collision, inherent in a higher platelet suspension, may in some way activate glycogen degradation, lactate production, and ATP depletion. It is also conceivable that high platelet suspensions become relatively anaerobic and consequently activate glycogenolysis. It is thus suggested that all previous metabolic data be interpreted with caution, since platelet concentration is a new variable important in the interpretation of these data.

\section{ACKNOWLEDGMENTS}

We are indebted to Doctors Aaron Kellner, Fred H. Allen, Jr., and Carlos Ehrich of The New York Blood Center for their cooperation in the supply of fresh platelet-rich plasma.

This work was supported by a Research Grant-in-Aide from the New York Heart Association.

\section{REFERENCES}

1. Karpatkin, S. 1967. Studies on human platelet glycolysis. Effect of glucose, cyanide, insulin, citrate, and agglutination and contraction on platelet glycolysis. J. Clin. Invest. 46: 409.

2. Luganova, I. S., I. F. Seits, and V. Teodorovich. 1958. Metabolism in human thrombocytes. Biochemistry. 23: 379.

3. Karpatkin, S., and R. M. Langer. 1968. Biochemical energetics of simulated platelet-plug formation. Effect of thrombin, adenosine diphosphate, and epinephrine on intra- and extracellular adenine nucleotide kinetics. J. Clin. Invest. $47: 2158$.

4. Karpatkin, S., and R. M. Langer. 1969. Human platelet phosphorylase. Biochim. Biophys. Acta. 185: 350.

5. Karpatkin, S., and R. M. Langer. 1969. Activation of inactive phosphorylase dimer and monomer from human platelets with magnesium adenosine triphosphate. $J$. Biol. Chem. 244: 1953.

6. Karpatkin, S. 1969. Heterogeneity of human platelets. I. Metabolic and kinetic evidence suggestive of young and old platelets. J. Clin. Invest. 48: 1073.

7. Bray, G. A. 1960. A simple efficient liquid scintillator for counting aqueous solutions in a liquid scintillation counter. Anal. Biochem. 1: 279.

${ }^{4}$ Murphy, S. Personal communiration. 
8. Steinetz, K. 1967. Laboratory diagnosis of glycogen diseases. Advan. Clin. Chem. 9: 227.

9. Villar-Palasi, C., and J. Larner. 1961. Insulin treatment and increased UDPG-glycogen transglucosylase activity in muscle. Arch. Biochem. Biophys. 94: 436.

10. Pogell, B. M., and K. Taketa. 1965. Allosteric inhibition of rat liver fructose-1,6-diphosphatase by adenosine 5'-monophosphate. J. Biol. Chem. 240: 651.

11. Mendecino, J., and F. Vasarhely. 1963. Renal D-fructose 1,6-diphosphatase. J. Biol. Chem. 238: 3528.

12. Rosen, O. M., S. M. Rosen, and B. L. Horecker. 1965. Purification and properties of a specific fructose-1,6diphosphatase from Candida utilis. Arch. Biochem. Biophys. 112: 411.

13. Pontremoli, S., E. Grazi, and A. Accorsi. 1966. Fructose diphosphatase from rabbit liver. VII. Tyrosine residues and adenosine monophosphate inhibition. Biochemistry. 5: 3568 .

14. Scott, R. B. 1967. Activation of glycogen phosphorylase in blood platelets. Blood. 30: 321.
15. Leloir, L. F., and C. E. Cardini. 1957. Biosynthesis of glycogen from uridine diphosphate glucose. J. Amer. Chem. Soc. 79: 6340.

16. Vainer, H., and R. Wattiaux. 1968. Glycogen synthetase in blood platelets. Nature (London). 217:951.

17. Krebs, H. A., D. A. H. Bennet, P. Gasquet, T. Gascoyne, and T. Yoshida. 1963. Renal Gluconeogenesis. The effect of diet on the gluconeogenic capacity of rat kidney cortex slices. Biochem. J. 86: 22.

18. Taketa, K., and B. M. Pogell. 1963. Reversible inactivation and inhibition of liver fructose-1,6-diphosphatase by adenosine nucleotides. Biochem. Biophys. Res. Commun. 12: 229.

19. Weber, G., R. Singhal, N. Stamm, E. Fisher, and M. Mentendiek. 1964. Regulation of enzymes involved in gluconeogenesis. Advan. Enzyme Regul. 2: 1.

20. Krebs, H. A., E. A. Newsholme, R. Speake, T. Gascoyne. and P. Lund. 1964. Some factors regulating the rate of gluconeogenesis in animal tissues. Advan. Enzyme Regul. 2: 71 . 